\title{
Oxygen transfer rates and requirements in oxidative biocatalysis
}

\author{
Pedersen, Asbjørn Toftgaard; Rehn, Gustav; Woodley, John
}

Publication date:

2015

Document Version

Peer reviewed version

Link back to DTU Orbit

Citation (APA):

Pedersen, A. T., Rehn, G., \& Woodley, J. (2015). Oxygen transfer rates and requirements in oxidative biocatalysis. Poster session presented at Towards P450 Applications, Bischoffsheim, France.

\section{General rights}

Copyright and moral rights for the publications made accessible in the public portal are retained by the authors and/or other copyright owners and it is a condition of accessing publications that users recognise and abide by the legal requirements associated with these rights.

- Users may download and print one copy of any publication from the public portal for the purpose of private study or research.

- You may not further distribute the material or use it for any profit-making activity or commercial gain

- You may freely distribute the URL identifying the publication in the public portal

If you believe that this document breaches copyright please contact us providing details, and we will remove access to the work immediately and investigate your claim 


\section{Oxygen transfer rates and requirements in oxidative biocatalysis}

\section{Asbjørn Toftgaard Pedersen, Gustav Rehn, John Woodley}

DTU Chemical Engineering, Søltofts Plads 229, 2800 Kgs. Lyngby, Denmark

Biocatalytic oxidation reactions offer several important benefits such as regio- and stereoselectivity, avoiding the use of toxic metal based catalysts and replacing oxidizing reagents by allowing the use of oxygen. However, the development of biocatalytic oxidation processes is a complex task which requires simultaneous consideration of several issues regarding the process design and operation.

In this work, the oxygen requirements are analysed for different process scenarios, considering different biocatalyst formats and variation of the desired productivity. Also, the applicability of two different oxygen supply methods (bubbling and membrane aeration) investigated. Hollow fibre membrane contactors present an interesting alternative for reactor aeration, creating large specific areas (area/volume) of the gas/liquid interface. The modular design of membrane contactors, scaling-up is relatively straight forward (Gabelman and Hwang, 1999), and membrane contactors are implemented for various industrial applications (Klaassen et al., 2005).

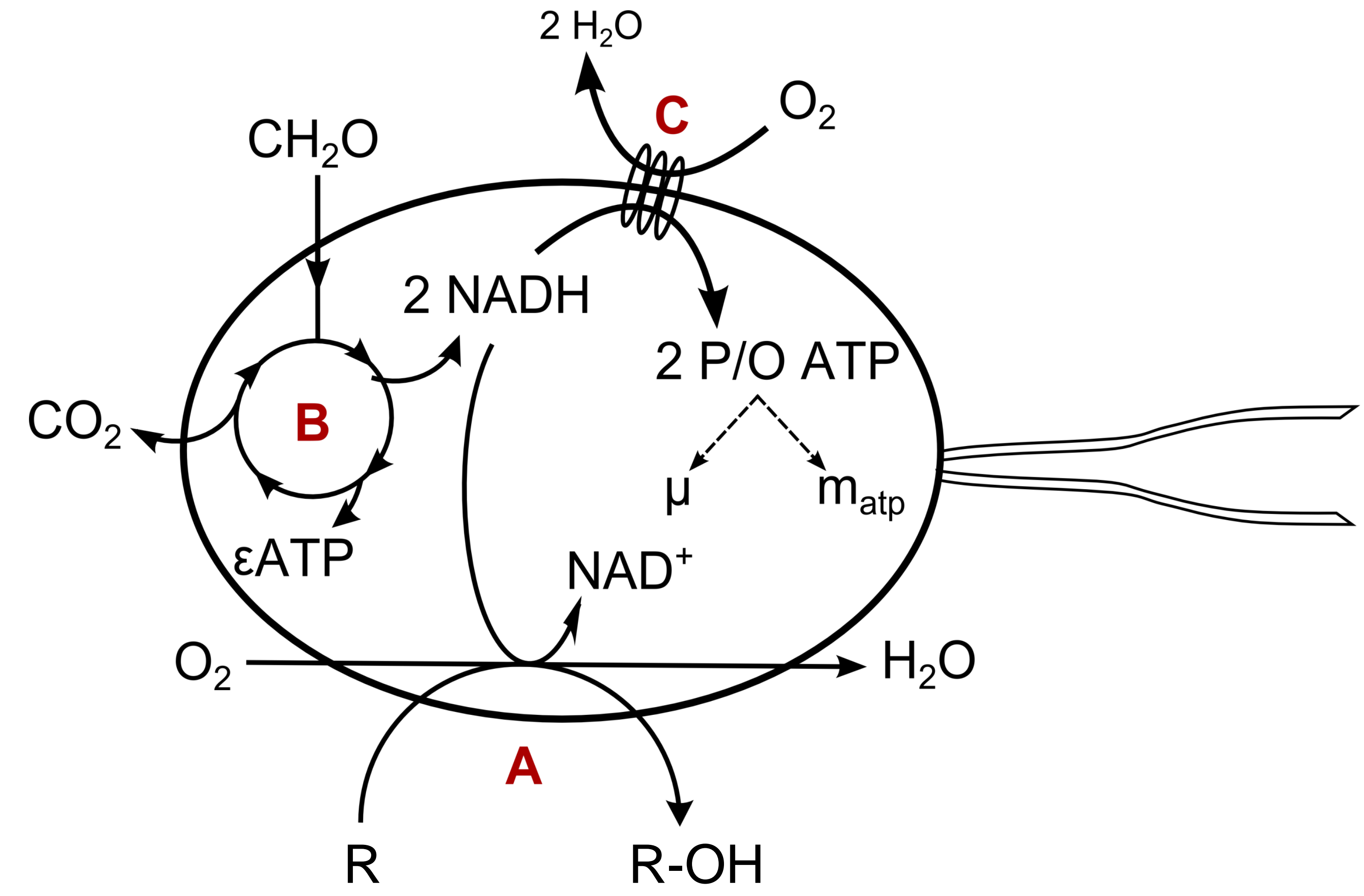

Figure 1. Illustration of a cell that catalyze a specific hydroxylation reaction (A), generates energy via the citric acid cycle (B) and the electron transport chain (C). The energy enables maintanence of cellular function $\left(\mathrm{m}_{\text {atp }}\right)$ and growth $(\mu)$.

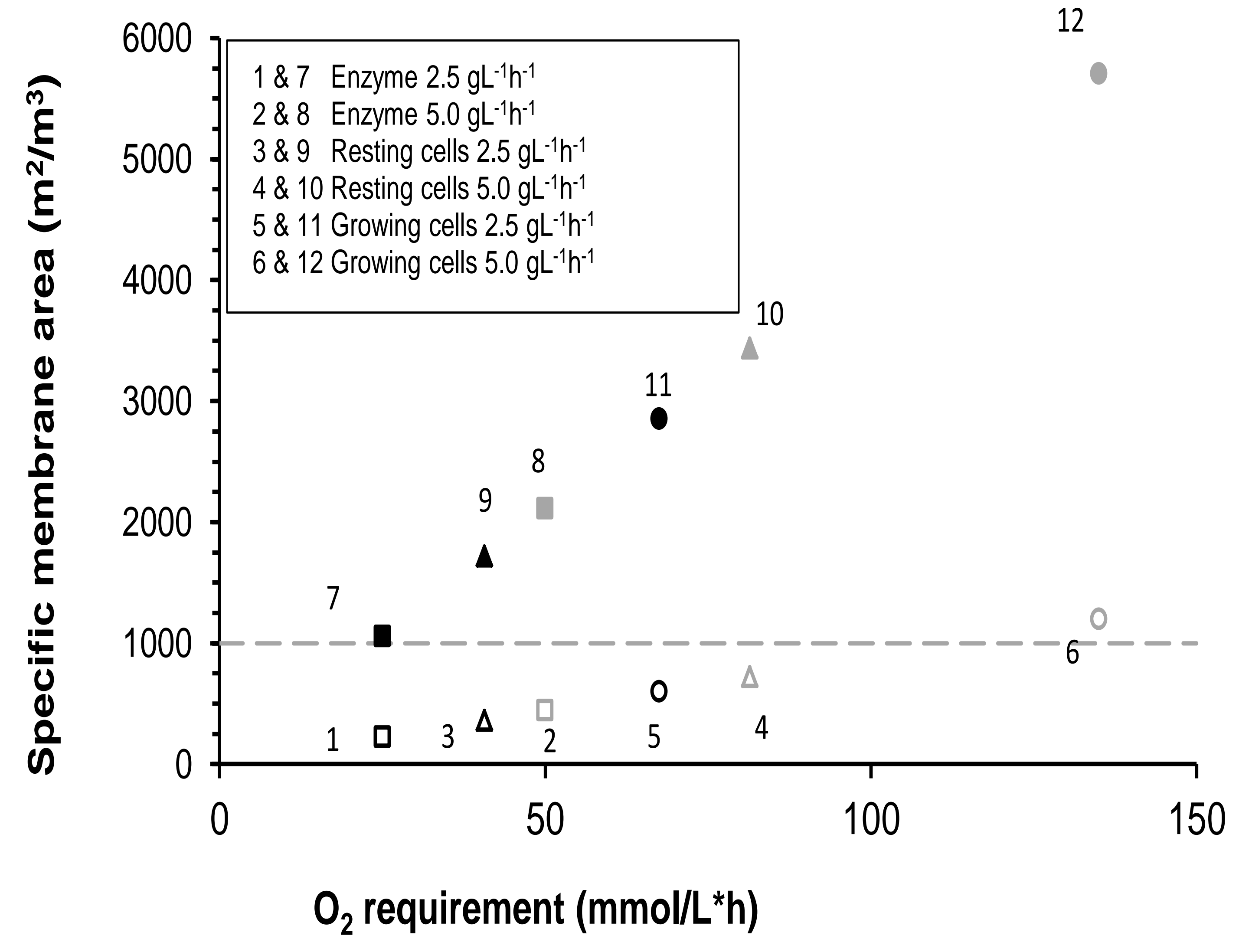

Figure 3 Examples of the estimated specific membrane area required for aeration of bio-oxidation processes, based on a volumetric productivity of $2.5 \mathrm{gL}^{-1} \mathrm{~h}^{-1}$ (black) or $5 \mathrm{gL}^{-1} \mathrm{~h}^{-1}$ (grey) respectively. Calculations are based on either the use of oxygen (open symbols) or air (closed symbols). The calculation were conducted as described previously (Cote et al., 1988), assuming an oxygen mass transfer coefficient of $3.8 \mathrm{~g} \mathrm{~m}^{-2} \mathrm{~h}^{-1} \mathrm{bar}^{-1}$ ) for a polypropylene hollow fibre (Côté et al., 1989) and operation at 1 bar. The dashed line represents a level where the design of commercial may become a

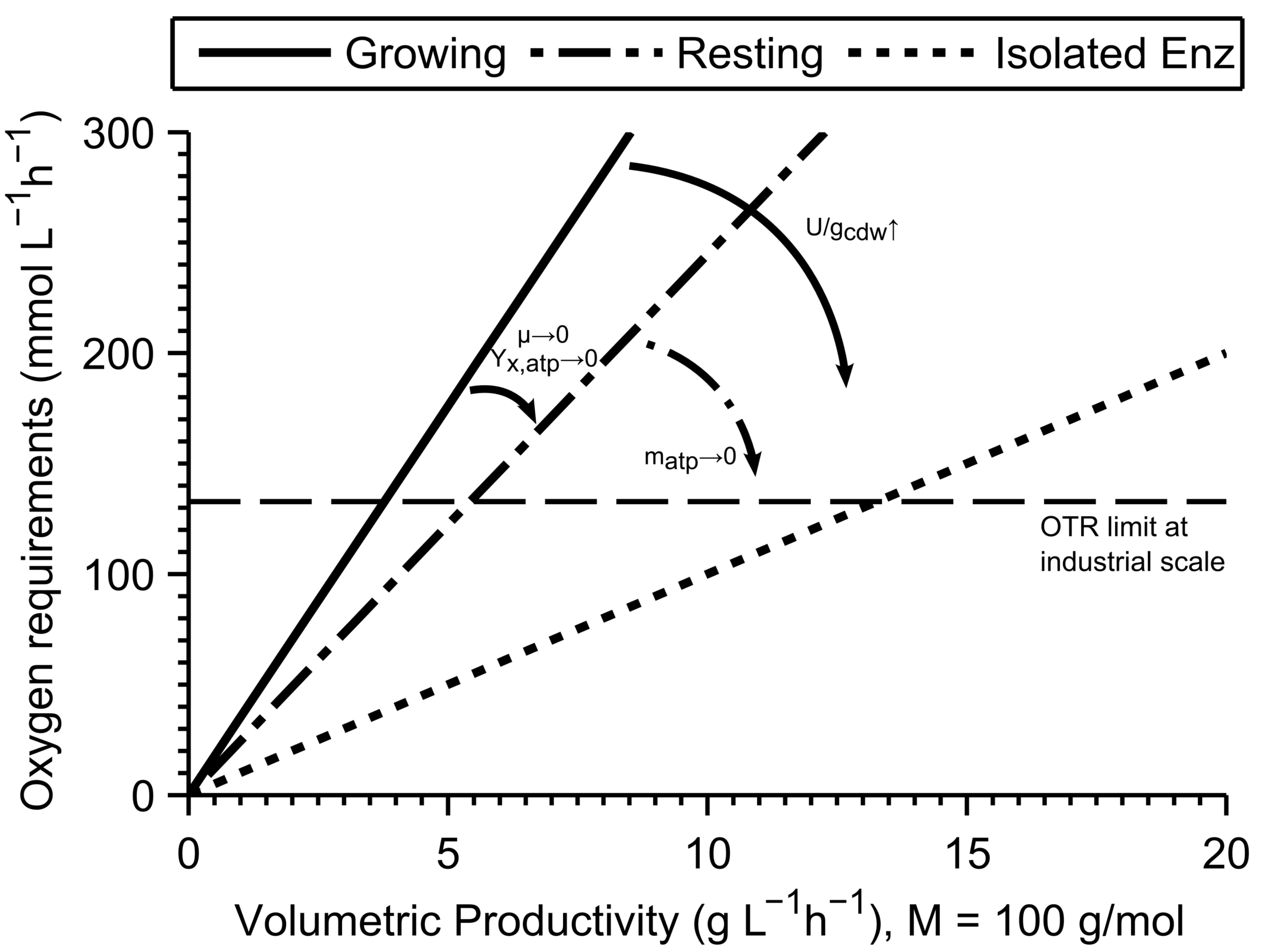

Figure 2 Oxygen requirements of different types of biocatalysts carrying out an oxidation reaction The calculations are based on $E$. coli and the following parameter values: $A_{\text {cat }}=50 \mathrm{U} / \mathrm{g}_{\text {cdw }}, \mu=0.2 \mathrm{~h}^{-1}$ $\varepsilon=2 / 3, P / O=1.5, Y_{X N A D D}=16.97 \mathrm{mmol} / \mathrm{g}_{\text {cdw }}, Y_{\text {xatp }}=70.2 \mathrm{mmol} / \mathrm{g}_{\text {cdw, }}, m_{\text {atp }}=7.9 \mathrm{mmol} / \mathrm{g}_{\mathrm{ccw}} / \mathrm{h}$ (Ingraham et al., 1983; Varma and Palsson, 1994). The maximum oxygen transfer rate (OTR) for bubble aeration the use of air.

\section{Oxygen requirements}

Figure 1 illustrates the overall metabolic processes of a cell catalysing a biooxidation reaction. By combining these catabolic reaction with the anabolic reaction for biomass synthesis (Eq. 1) a model for the oxygen consumption can be derived (Eq. 2) (Villadsen et al., 2011).

$(1-\alpha) \mathrm{CH}_{2} \mathrm{O}+Y_{x N A D P H} \mathrm{NADPH}+Y_{x A T P} A T P \longrightarrow X+\alpha \mathrm{CO}_{2}+Y_{x N A D H} \mathrm{NADH}$

$r_{O_{2}}=A \mu+B+C r_{c a t}$

$$
A=\underbrace{\frac{Y_{x A T P}-Y_{x N A D H} P / 0}{\varepsilon+2 P / 0}+\frac{1}{2} Y_{x N A D H}}_{\text {Growth }} \quad B=\underbrace{\frac{m_{A T P}}{\varepsilon+2 P / 0}}_{\text {Maintenance }} \quad C=\underbrace{\frac{1}{2}+\frac{P / 0}{\varepsilon+2 P / 0}}_{\text {Biocatalysis }}
$$

\section{Membrane aeration}

Because enzymes can be inactivated by gas/liquid interfaces (Bommarius \& Karau, 2005), bubble-less aeration through membranes may improve the operational stability of the enzyme. Figure 2 shows the estimated specific membrane areas necessary in order to reach given productivities using different forms of the biocatalyst.

\section{Conclusions}

- The maximum achievable productivity is greatly influenced by the oxygen requirement set by the biocatalyst.

- Maximum productivities of 3.5 and $5 \mathrm{gL}^{-1} \mathrm{~h}^{-1}$ were estimated for growing and resting cells respectively, using conventional bubble aeration

- Membrane aeration is limited in terms of the maximum oxygen flux. Thus, the use of pure oxygen may be necessary in order to support the desired productivity.

- Bubble-less aeration would be particularly relevant to systems using sensitive enzymes. It may also be beneficial in order to minimize the evaporation of volatile components.

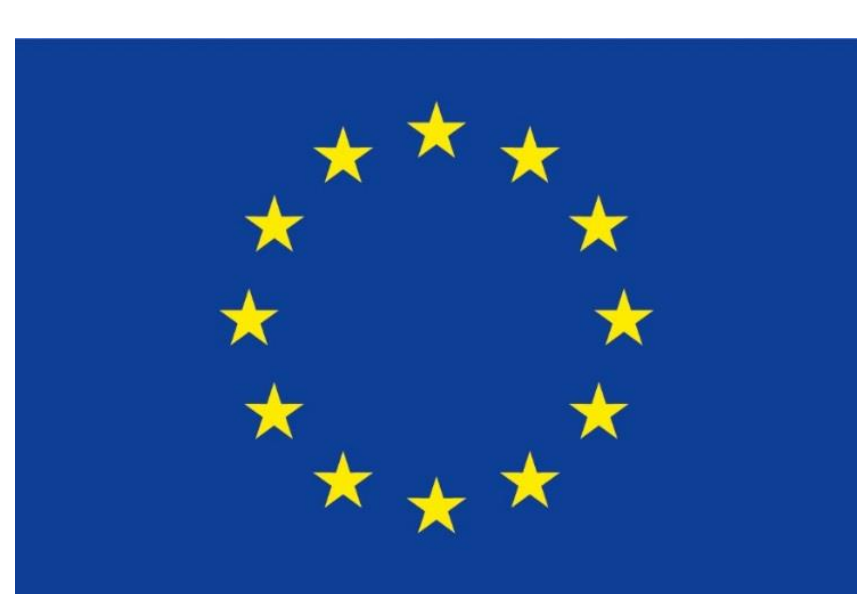

This project has received funding from the European Union's Seventh Framework Programme for research technological development and demonstration under grant agreement $n^{\circ} 613849$. 